\title{
BÁNFI SZILVIA
}

\section{BINDER JÁNOS FÜLÖP METSZETEI A MÁRIARADNAI KEGYKÉPRŐL A BUDAI LANDERER-NYOMDA KIADVÁNYAIBAN (1762-1771)}

A csodatevő máriaradnai kegyképről (ma Radna, Romániában) a 18. században többször is jelentek meg metszetmásolatok. Ezekkel a korábbi szakirodalom részletesen foglalkozott. A Typographica Hungarica 18. századi köteteinek előkészítése során azonban sikerült az eddig ismerteknél jóval bővebb anyagot feltárni, és a metszetek - s az őket tartalmazó nyomtatványok - egymáshoz való viszonyát megnyugtatóan tisztázni. Tanulmányunk a budai Landerer-nyomdában kiadott és illusztrált máriaradnai mirákulumos kötetekben szereplő Binder-illusztrációkat tekinti át, kibővítve a budai Landerer-tipográfia nyomdai anyagának rekonstruálása kapcsán nyert újabb információkkal.

Mai tudásunk szerint a budai Landerer-officinában az alábbi, Máriaradnához kapcsolódó nyomtatványok jelentek meg: ${ }^{1}$

1. 1756. - Nemorosa opacitas relucens seu genuina historia sacratissimae imaginis Beatissimae Virginis Matris Gratiarum, quae in Sacra Radnensi Aedicula Fratrum Minorum Observantium S. P. Francisci Provinciae Bosniae Argentinae jam 88. annis... Budae, Typis Leopoldi Francisei Landerer, Typog. 1756. (Petrik II. 928)

2. 1756. - A latin nyelvü változatot még az 1756 . esztendőben lefordították német nyelvre, amelyet a budai nyomda meg is jelentetett. Példánya nem maradt fenn. Emlékét az 1767. évi, harmadik német nyelvü kiadás előszava őrzi.

3. 1762. - Világos berkes hegy... Budán, Landerer Ferencz Leopold Betúivel, 1762-dik esztend ben. (Petrik I. 249)

4. 1763. - Wunder-scheinender Wald-Schatten oder ausfuhrlicher Bericht des wundert- hätigen Gnaden-Bildes der aller seeligsten Jungfrauen Mariae.... zu Radna in Ungarn... Ofen, gedruckt bey Leopold Franz Landerer, 1763. (Petrik III. 822)

5. 1767. - Wunder-scheinender Wald-Schatten oder ausfuhrlicher Bericht des wunderthätigen Gnaden, Bildes der allerseligsten Jungfrauen Mariae... Ofen, gedruckt bey Leopold Franz Landerer, 1767. (Petrik V. 554)

6. 1771. - Wunderscheinender Wald-Schatten, oder Ausführlicher Bericht des wunderthätigen Gnaden Bildes der... Jungfrauen Mariae ... zu Radna in Ungarn... Ofen, gedruckt mit Landerischen Schriften. 1771. (Petrik V. 554, rézmetszet-sorozattal)

7. 1771-1773? - Wunderscheinender Wald-Schatten, oder Ausführlicher Bericht des wunderthätigen Gnaden-Bilds der... Jungfrauen Mariae, so zu Radna in Ungarn... Ofen, gedruckt mit Landerischen Schriften. 1771. (Petrik V. 554, fametszetes sorozattal)

A pozsonyi származású rézmetsző, Johann Philipp Binder (a továbbiakban Binder János Fülöp) (1736?-1811) múvészeti tanulmányait Bécsben folytatta. A császárvárosban nősült 1760. augusztus 3-án. Felesége, a bécsi származású Gruber Éva maga is grafikus volt. Egyik házassági tanújuk a budai nyomdász, Landerer Lipót Ferenc volt. A későbbiek szempontjából ez a tény fontos adalék, és megmagyarázza a budai Landerer-nyomda és a jeles rézmetsző szoros együttmüködését. ${ }^{2}$ Binder János Fülöp első, már Budán szignált müve az 1759es évszámot viseli. ${ }^{3}$ Jelenlegi ismereteink szerint a budai Landerer-mühelyben nyomtatott kötetekben Bindernek először az 1761. évtől szerepeltek a réz- 


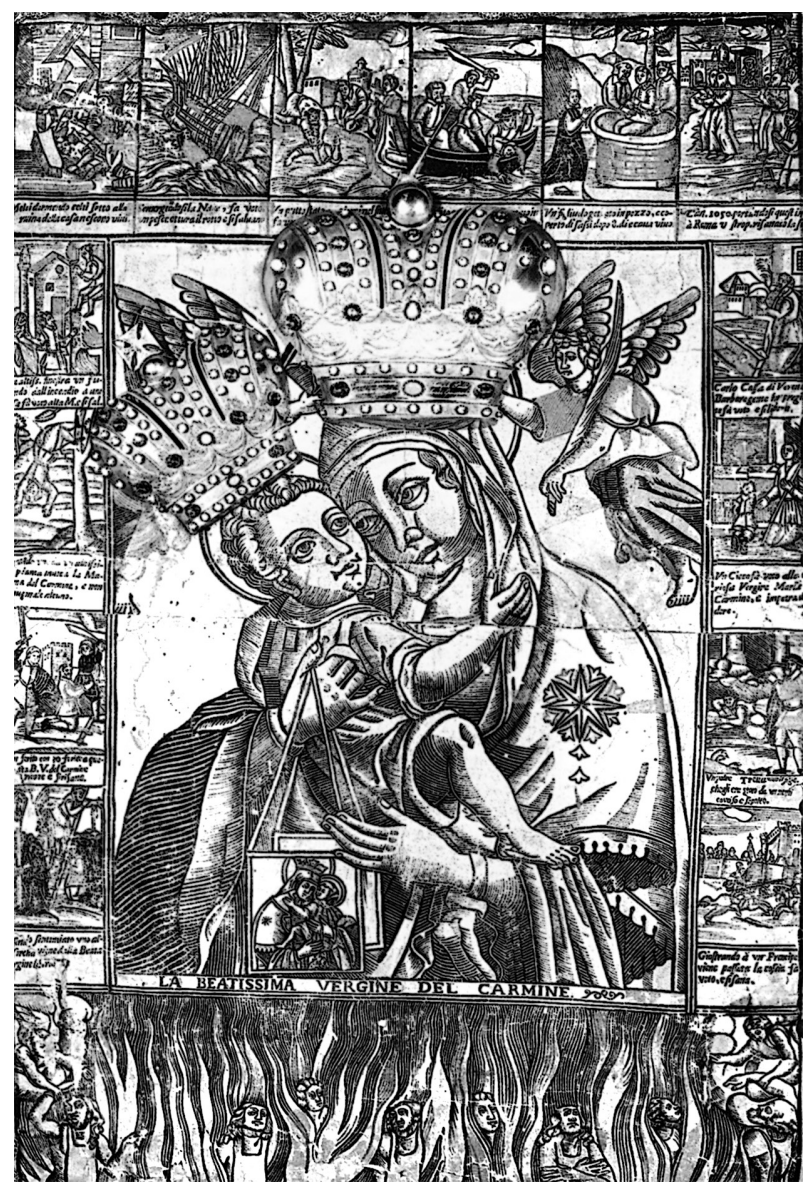

1. A Skapulárés Szüzanyát ábrázoló színes papírnyomat, az itáliai eredetü máriaradnai kegykép

metszetei. Ebben az esztendőben látott napvilágot Paulus Lucas Perghold De rege et cive... címü müve, ${ }^{4}$ amelynek címlapelőzéke Binder emblémametszete. ${ }^{5}$ Ugyancsak az 1761 . évben nyomtatta ki a Landerer-tipográfia Buda látképét, ${ }^{6}$ amelynek jobb alsó sarkában olvasható a metsző szignatúrája: Jo. Philip Binder sc. Budae. 1761. Mindebből arra következtetünk, hogy kettőjük szorosabb munkakapcsolata az 1761. esztendőtől kezdve vált folyamatossá.

Binder János Fülöp a számos városkép, címeres levél mellett nagyszámú szentképet is metszett. Közöttük található az a címlapelőzék és rézmetszetsorozat, amely a Skapulárés Boldogasszonyt ábrázoló máriaradnai kegykép ${ }^{7}$ megmenekülésének történetét grafikailag megjeleníti.

Máriaradna, a híres búcsújáró hely az Alföld délkeleti szegletén, a Maros partján, az Erdély határát jelző Zarándi-hegyek lábánál, az egykori Arad vármegyében található. Szakrális jelentősége a 17. századig nyúlik vissza, amelynek történeti előzménye a következő.

1668-ban a bosnyák származású Virchnossa György megvásárolta egy olasz papírkereskedőtől a Skapulárés Szűzanya itáliai eredetű, színezett pa- pírképét. ${ }^{8}$ Ezt utóbb - nem sokkal a halála előtt - a radnai ferenceseknek ajándékozta, akik fából épült kápolnájukban helyezték el, nyilvános tiszteletre. 1695-ben, Lippa visszafoglalása idején a portyázó törökök Radnára is betörtek, és felgyújtották a kápolnát, amely teljesen leégett, ám a kegykép csodával határos módon nem pusztult el. A haláluk után a lelkeknek a tisztítótüzből menekülést ígérő Skapulárés Szüzanyát ábrázoló radnai kegyképhez ezt követően törökellenes tartalom is tapadt. Ez az esemény, valamint a kegyképhez később kapcsolódó csodás gyógyulások alapozták meg, hogy Máriaradna évszázadokon át az ország egyik legfontosabb búcsújáró helye lett. ${ }^{9}$

A kegykép csodálatos megmenekülése történetét a 18. században megjelent munkák terjesztették el. A kegyképpel kapcsolatos csodákat elbeszélő, ismeretlen szerzőtől származó - latinul, magyarul és németül megjelentetett - írásmű igen népszerűvé vált. Kezdetben Budán, majd a század utolsó harmadában Temesváron ${ }^{10}$ és Vácott ${ }^{11}$ is kinyomtatták, sőt hatása még a 19. században is kimutatható. ${ }^{12}$

A budai Landerer-nyomdában a radnai kegyképpel kapcsolatos történésekről beszámoló írásmü első alkalommal 1756-ban jelent meg Nemorosa opacitas relucens seu genuina historia sacratissimae imaginis... címmel, latin nyelven. ${ }^{13}$ Ezt a kiadást a budai mühely még a kegyképhez kötődő illusztrációsorozat nélkül hozta forgalomba.

Máriaradnával kapcsolatos, ma példányból is ismert újabb kiadványt legközelebb az 1762. évben nyomtatott a budai Landerer-tipográfia Világos berkes hegy... címen, ${ }^{14}$ immár magyar nyelven, amelyben legelőször szerepelt Binder címlapelözéke, illetve a teljes nevével szignált rézmetszet-sorozat.

A címlapelőzék a kegyképet ábrázolja a templom és a kolostor látképével. A rézmetszet felirata: „Monstra te esse matrem. Duc eum ad Mariam. Egeni aspicite matrem. Ecce matrem vestram." Binder szignatúrája a jobb alsó sarokban olvasható: I. Philipp Binder. Sc. Budae. ${ }^{15}$ Ezt a metszetet a budai Landerer-tipográfia az 1769. évben megjelentetett Varia pietatis exercitia... ${ }^{16}$ címú kötetben is felhasználta címlapelőzékként (2. kép). Megalapozottan feltételezhetjük tehát, hogy a Skapulárés Boldogaszszony radnai csodáját elbeszélő Wunder-scheinender Wald-Schatten... címü, 1763-ban ${ }^{17}$ és 1767-ben ${ }^{18}$ németül megjelentetett nyomtatványokban szintén szerepelhetett ez a rézmetszetes címlapelőzékmetszet. Csonkítás miatt azonban ma már mindkét kiadás fennmaradt példányaiból hiányzik a Binderféle metszetes címlapelőzék.

A német nyelvü kiadások sikerét érzékelve a budai Landerer-múhely az 1771-es impresszum tanúsága szerint németül immár negyedszerre is meg- 

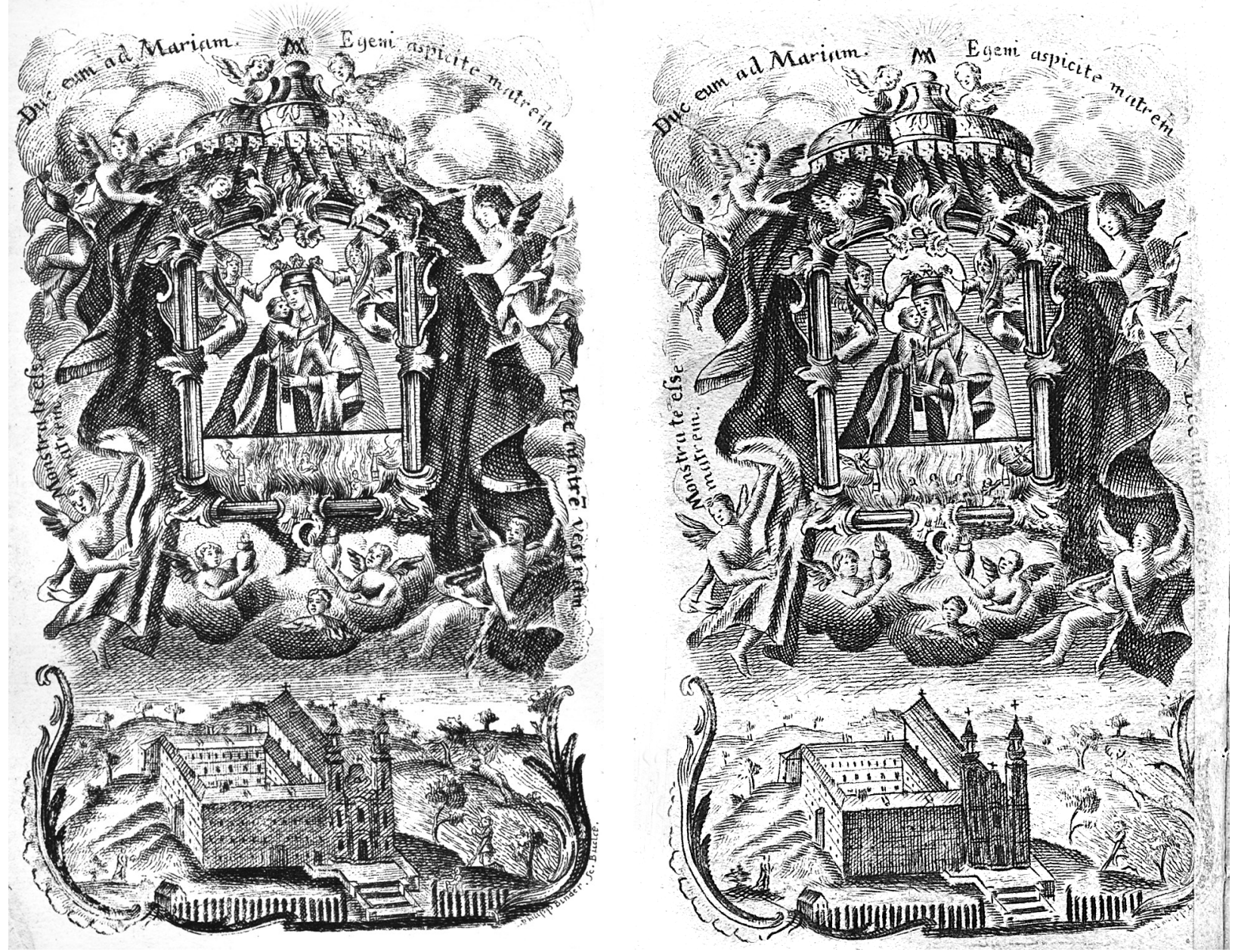

2-3. A máriaradnai Skapulárés Szúzanya kegyképe a templommal és a kolostorral.

Binder János Fülöp eredeti, 1762. évi rézmetszete (1. változat), illetve az 1771. évtól alkalmazott utánmetszett rézmetszet (2. változat)

jelentette a csodatevő máriaradnai kegykép történetét, ez alkalommal két, eltérő technikával készült könyvillusztrációval és kétféle szedésben. ${ }^{19}$ A népszerü kiadványt a „vásárlók különböző igényeit és anyagi lehetőségeit" ${ }^{20}$ szem előtt tartva rézmetszetes és fametszetes képsorozattal adták ki. Címlapelőzéke egykoron mindkettőnek volt, de csak az 1771. évi rézmetszet-sorozattal megjelentetett kiadásban őrződött meg. Ez a kegyképet szintén a templom és a kolostor látképével együtt ábrázolta. Nem azonos azonban a Binder János Fülöp által metszett, 1762. évi kiadásokból ismeretes első címlapelőzékkel (2. kép), hanem annak utánmetszett, pontos mása (3. kép). A felirat ugyanaz: „Monstra te esse matrem. Duc eum ad Mariam. Egeni aspicite matrem. Ecce matrem vestram." ${ }^{21}$ A szignatúra sajnos elmosódott, olvashatatlan (5. kép). Bár a szakirodalomban ezt a változatot is Binder alkotásának tekintik, ${ }^{22}$ mégis úgy véljük, hogy ez egyértelmüen nem dönthető el. Feltételezésünk szerint nem zárható ki, hogy ez a metszet-változat nem Binder sajátja, hanem talán az általa alapított budai mühelyében dolgozó metszők egyikének munkája lehetett. $^{23}$

Az 1771. évi impresszummal megjelentetett fametszetes képsorozatot tartalmazó változatból az előlapot ugyancsak kitépték. Az egykori metszet jobb széléből azonban a beragasztás miatt egy piciny rész megmaradt, és ez segítette az azonosítást. Megállapítható, hogy az 1773. évi temesvári kiadásban ${ }^{24}$ szereplő, a Binder-féle mühely által készített újabb - a kegyképet, valamint a templomot és a kolostort ábrázoló - metszet-változat ${ }^{25}$ már 1771-re elkészült (6-7. kép). Ez a címlapelőzék-metszet az eredeti, 1762. évi metszettől tartalmában nem, de megjelenítésében teljesen eltér. Az eredetinek tehát nem utánmetszett változata. Itt a metsző a Skapulárés Boldogasszonyt képkeretben, ez alatt a máriaradnai templomot a kolostorral kartusban ábrázolta. Erre a címlapelözékre nem került szöveg (6. kép). 


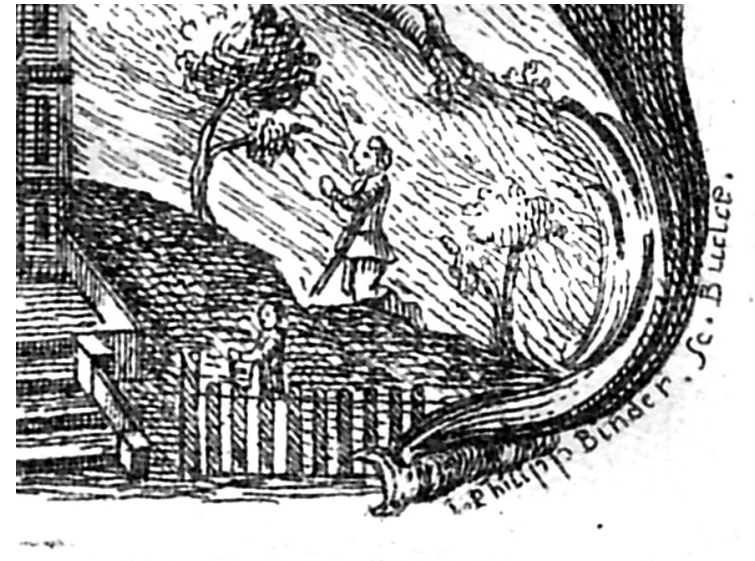

4. Binder János Fülöp eredeti,

1762. évi szignatúrája (1. változat)

Összegzésként megállapíthatjuk, hogy az 1762ben készült címlapelőzék (2. kép) a budai Landerer-nyomda kiadványaiban minden bizonnyal csak 1762 és $1769^{26}$ között volt használatban. Feltehetően az 1771. évre ennek a metszetnek a réz nyomólemeze már nem állt rendelkezésre. Valószínúleg annyira elkopott, hogy pótolni kellett. Ezért készülhetett az eredetivel szinte azonos utánmetszett második (3. kép), illetve az eddig csak az 1773. évi temesvári kiadásból ismeretes, későbbinek gondolt, új metszésű (6. kép), felirat nélküli változat. Vagyis a budai tipográfia három különböző rézmetszetes címlapelőzékkel hozta forgalomba az általa megjelentetett máriaradnai mirákulumos köteteket.

A következőkben részletesen szólunk a máriaradnai Skapulárés Szűzanyát ábrázoló kegyképhez kötődő kétfajta metszetsorozatról. Mai tudásunk szerint a budai Landerer-nyomda a máriaradnai mirákulumos könyveket 1762-től kezdődően 1771ig minden esetben Binder János Fülöp rézmetszetsorozatával illusztrálva jelentette meg. ${ }^{27}$ Kivételt az egy fametszetes sorozattal illusztrált, és szintén 1771. évi impresszummal megjelentetett német nyelvú kiadás esetében tett a budai mühely. Mind a két technikával készült illusztrációsorozat 11 tagból áll, és alkalmazásuk során a rézmetszetes és a fametszetes sorozat esetében is a 6. számú kép szerepelt két alkalommal. Az 1771. évi rézmetszetsorozat esetében szólnunk kell még arról is, hogy e sorozat utolsó tagját, amely ekkorra már nyilván hiányzott, szintén utólag metszett másikkal pótolták. A beteg Brumer Anna Mária látomását megjelenítő metszet tükörfordított, és a korábbinak nem pontosan újra metszett változata. Talán ezt a rézmetszetet is ugyanaz a személy készíthette el, aki a címlapelözékként szerepeltetett máriaradnai kegykép második változatát utánmetszette. Alkotója a rézmet-

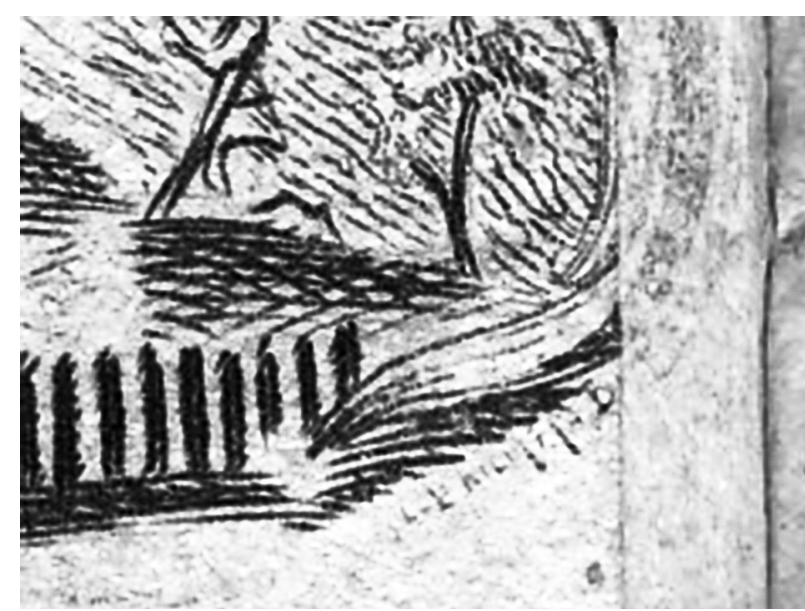

5. Az utánmetszett rézmetszet elmosódó, olvashatatlan szignatúrája (2. változat)

szetsorozat utolsó tagjának újra metszésénél nem az eredeti sorozatba tartozó képet vette mintául. Az új metszet tartalmában ugyan azonos az eredetivel, de metszője a tükörfordított kivitelezésen túl, lényegesen más, attól eltérő képi ábrázolást alkalmazott (8-9. kép). Ennek az lehet a magyarázata, hogy a rézmetszetsorozat utólag pótolt 11. tagjának készítésekor a metszőnek nem állt rendelkezésre sem az eredeti sérült rézlemez, sem annak levonata. Ugyanakkor a fametszetes sorozat esetében egyértelmúen megállapítható, hogy a sorozat utolsó fametszete az eredeti rézmetszet-sorozat (vagyis az 1762-1767 között használt) 11. tagjával megegyező, azt pontosan követő változat (10-11. kép).

A kétféle technikával készített, 1771. évi impresszumot viselő, azonos méretű német nyelvú mirákulumos kötetek tipográfiai vizsgálata alapján megállapítható, hogy nemcsak eltérő illusztrációkkal, hanem más-más betütípusokkal és könyvdíszekkel nyomtatták ki őket. A rézmetszetsorozattal illusztrált kiadás betűi a megelőző, de inkább az 1767. évivel mutatnak hasonlóságot. ${ }^{28}$ Megtalálható benne az 1756. január 6-i engedélyezés mellett a Fr. Benedictus Zebich Vicarius Provinciális Temesváron, 1767. január 31-én kelt, az újabb megjelenést engedélyező hozzájárulása is. ${ }^{29}$ Ezekből az írásokból az is kiderül, hogy a latin nyelvű változatot hamarosan lefordították németre, amely, ahogyan korábban említettük, még 1756-ban meg is jelent. Példánya sajnos nem ismeretes. A budai Landerertipográfia a radnai kegyképpel kapcsolatos történésekről beszámoló német nyelvű mü harmadik, 1767. évi kiadását követve jelentette meg 1771-ben az újabb rézmetszetes változatot, tipográfiailag tulajdonképpen a korábbi kiadásokéval megegyező formában és kivitelben.

A megjelenítését tekintve ötödik német nyelvű kiadás, a fametszetsorozattal illusztrált változat 

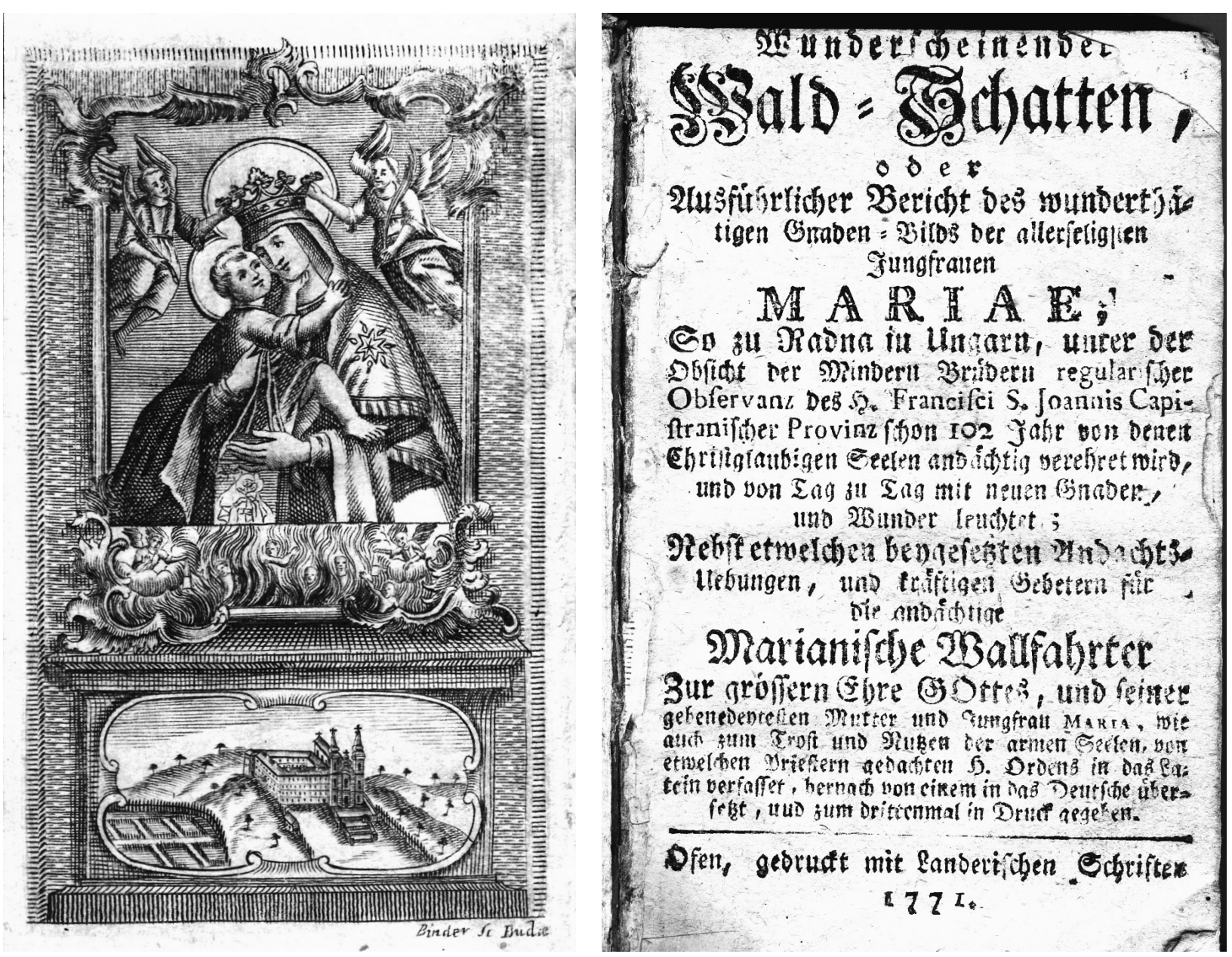

6-7. Az 1771-ben Budán megjelent, fametszetes illusztrációsorozatot tartalmazó kiadványba a máriaradnai kegyképnek valószínüsíthetően ez az új metszésü rézmetszetes változata került címlapelőzékként (3. változat)

viszont ettől eltérő, más. Ebben a kiadásban nem szerepel az 1767. évi megjelentetés engedélyezése, amely valószínúleg a rézmetszet-sorozattal megjelentetett kiadásokra vonatkozott. Itt ezért elhagyták. Ugyanakkor az ebben a változatban szereplő betútípusok újabb beszerzések, amelyeket 1770-től alkalmazott a budai Landerer nyomda.

Ezek után felvetődik a kérdés, hogy valóban kétszer jelentették-e meg egy éven belül német nyelven a máriaradnai Skapulárés Szűzanya csodatételét elmesélő mirákulumos kötetet? Ha mégsem így történt, akkor továbbra is kérdéses: a fametszetsorozattal kiadott nyomtatvány mikor jelent meg? Meglátásunk szerint feltehetóen az 1771-es rézmetszetes sorozatot tartalmazó kötetek elfogyhattak. A Landerer nyomdának üzleti érdeke lehetett a folyamatosan jelentkező nagyfokú vásárlói igény kielégítése. Ezért dönthetett az újabb megjelentetés mellett. Valószínűsíthetően addigra a rézlemezek már használhatatlanokká váltak. Nincs arról tudomásunk ugyanis, hogy ezeket a Landerer tipográfia, vagy bármely más korabeli magyarországi nyomtató műhely utóbb alkalmazta volna. Ezért kerülhetett sor a fametszetsorozat megrendelésére. Felmerülhet az a lehetőség is, hogy annak elkészültét követően a budai műhely még az 1771 . esztendőben kinyomtatta e népszerủ múvet a fametszetsorozattal. Ennek viszont ellentmond a kötetben szerepeltetett címlapelőzék, amely, amint azt az előzőekben megállapítottuk, az 1773. évi temesvári kiadásból ismeretes új metszésű változat volt. Nem valószínü, hogy a budai műhely egy azon esztendőben, azonos múvet két különböző rézmetszetes címlapelőzék-metszettel jelentetett volna meg. Meglátásunk szerint ezért a fametszetes sorozattal illusztrált kötet 1771-nél később jelenhetett meg. De ami biztos, az az, hogy ennek a mirákulumos kötetnek a kiadása mindenképpen legkésőbb az 1773. év elején megtörtént. Ugyanis ezt a fametszetsorozatot és a harmadik címlapelőzéket (6. kép) ez után, az 1773. év folyamán már a temesvári Matthaeus Josef Heimerl alkalmazta, aki a Világos berkes hegy... ${ }^{30}$ címen általa 

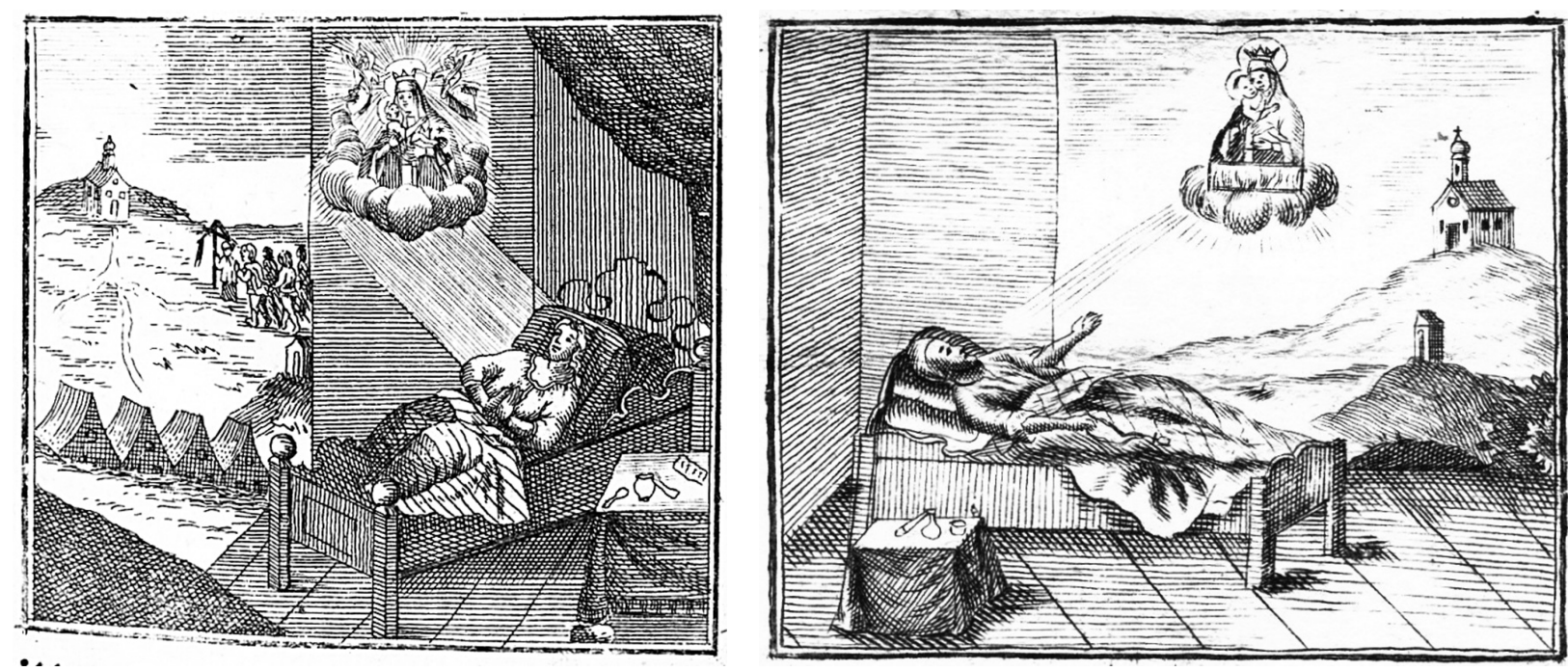

8-9. A rézmetszetsorozat 11. tagjának eredeti (1762. évi) és újra metszett, tükörfordított változata (1771. évi)

kiadott magyar nyelvű nyomtatványban szerepeltette ezeket az illusztrációkat. A század végén, 1796ban pedig a fametszetsorozat már a váci nyomda használatában volt. ${ }^{31}$

A budai Landerer nyomdában a Máriaradnához kapcsolódó újabb mirákulumos kötet megjelentetéséről 1771/1773?-at követően nincs ismeretünk. Tisztázandó viszont, hogy az újrametszett címlapelőzék, valamint a fametszetsorozat ezt követően milyen úton-módon jutott el Budáról Temesvárra? Lehetett-e személyes kapcsolat a budai nyomtató mủhely, valamint a temesvári nyomda között? Ismeretes, hogy Temesváron már 1766ban kísérlet történt nyomda felállítására. Két jelentkező is akadt, akik nyomdát kívántak működtetni a városban. Közülük Anton Kolbot, a budai Landerer

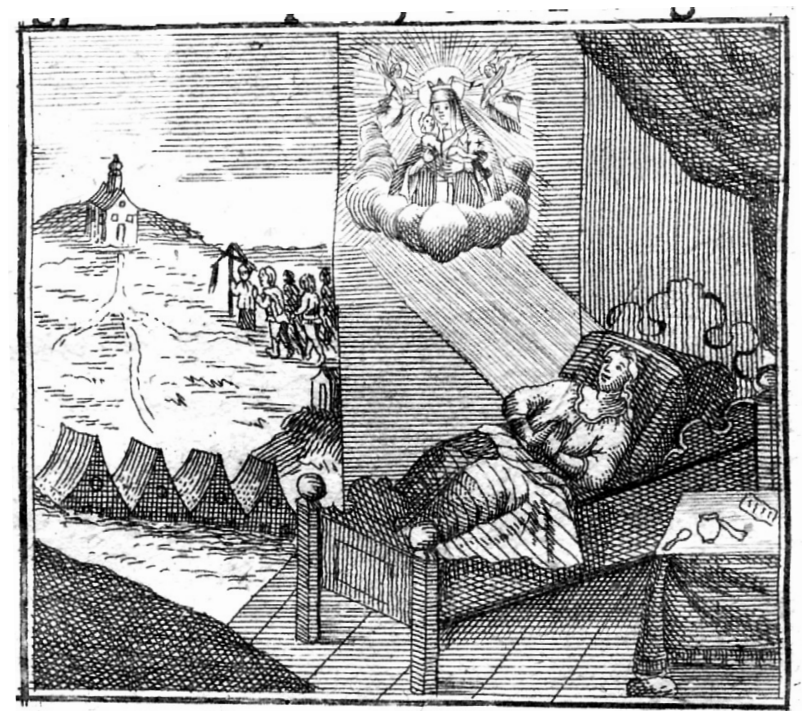

nyomda művezetőjét a temesvári tanács is támogatta nyomdaalapítási szándékában, hiszen értett a réznyomtatáshoz, továbbá felesége is jártas volt a nyomdászmesterségben. ${ }^{32}$ Törekvésüket azonban a Kamara még ekkor megakadályozta. Ennek ellenére Anton Kolbnak talán mégis lehetett közvetítő szerepe mind az újrametszett címlapelőzékmetszetnek (6. kép), mind a fametszetsorozatnak, amely valószínúleg szintén a Binder-mühelyben készülhetett, a temesvári nyomdához való eljuttatásában. De annak a lehetőségét sem zárhatjuk ki, hogy a Binder-féle múhely tulajdonaként egyenesen őtőlük került a címlapelőzék-metszet, valamint a fametszetsorozat Temesvárra, majd utóbb, 1796ban már csak a fametszetes képsorozat Vácra. Ez utóbbi kiadás unikális példányának ismeretében

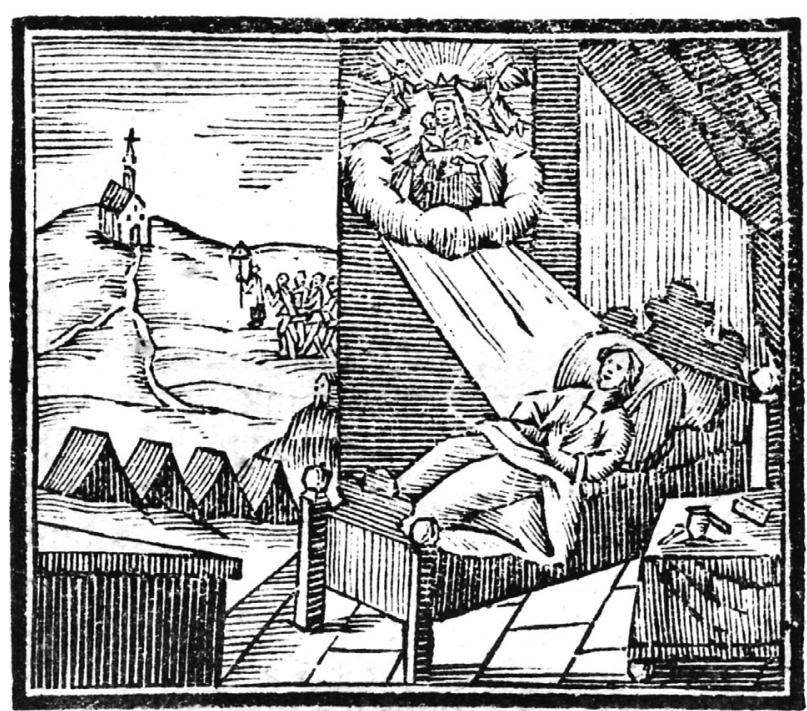

10-11. A rézmetszetsorozat eredeti 11. tagja és az arról készült fametszetes változat 
sem dönthető el teljes bizonyossággal, hogy egykoron rendelkezett-e címlapelőzékkel. ${ }^{33}$ Vagyis a máriaradnai kegyképet a templommal ábrázoló újrametszett címlapelőzék (6. kép) rézlemeze rendelkezésre állt-e még 1796-ban is?

A máriaradnai kegyképhez kapcsolódó irodalmi mü, amint azt korábban már említettük, a 19. században is igen népszerü volt. A magyar nyelvű változatot 1805 -ben a budai Egyetemi nyomda, ${ }^{34}$ 1824ben pedig Pesten, Trattner János Tamás jelentette meg. ${ }^{35}$ Wunderzeichen an der Wald-Schatten... címen 1820-ban, Aradon Anton Michok által megjelentetett egykori német nyelvű kiadását Jordánszky Elek említi. ${ }^{36}$ Mai tudásunk szerint példánya nem ismeretes. Horvát nyelvű változatban 1824-ben, ugyancsak Aradon a Michok-tipográfia, ${ }^{37}$ majd néhány évtizeddel később, 1856-ban, Budán Bagó Márton ${ }^{38}$ adta ki. 1810-ben, Szegeden Dugonics András Radnai történetek című kötetét a Grün-nyomda jelentette meg. ${ }^{39}$ Ennek 1843. évi második, név nélküli kiadása ugyancsak ebben a szegedi nyomtató mühelyben készült. ${ }^{40}$ Egyetlen fennmaradt példánya Bálint Sándor tulajdonában megvolt. ${ }^{41}$

A budai Landerer-nyomdában használt, a kegyképhez kapcsolódó könyvillusztrációk további előfordulását követve vizsgáltuk meg az előzőekben felsorolt kiadványokat. Ennek alapján a következő megállapításra jutottunk. A 18. században alkalmazott három, vagyis az eredeti 1762. évi, az erről készült 1771. évi utánmetszett, valamint az 1771-1773 között újra metszett címlapelőzékek egyike sem szerepelt a 19. században megjelentetett kötetekben. Ugyanakkor 1824-ben a Trattner-nyomda kiadásában megjelentetett magyar nyelvü kiadványban az 1771-1773 közötti időszakban alkotott címlapelőzék-metszet (6. kép) alapján készített újabb, korábban nem ismeretes jelöletlen címlapelőzékmetszet tünt föl (12. kép).

Az 1771-1773 között Budán, 1773-ban Temesváron, 1796-ban Vácon alkalmazott fametszetsorozat 1805-ben a budai Egyetemi nyomda kiadott kötetben, 1824-ben pedig Aradon, az Anton Michok által horvátul megjelentetett kiadványban szerepelt. Az utóbbi kötetben, eltérően a korábbi kiadások mindegyikétől, a 11 tagból álló sorozat képei közül a 6. tagot nem szerepeltette kétszer a tipográfus. A képsorozat utolsó alkalmazására valószínủleg 1843-ban, a szegedi Grün-tipográfiában kinyomtatott Radnai történetek címú Dugonics müben kerülhetett sor. Az egyetlen példányban fennmaradt nyomtatványról tulajdonosa, Bálint Sándor a következőket írta: „Klasszikusnak tekinthető népszerűségére mi sem jellemzőbb, hogy Szegeden 1843-ban Grün Jánosnál új kiadásban, de már név-

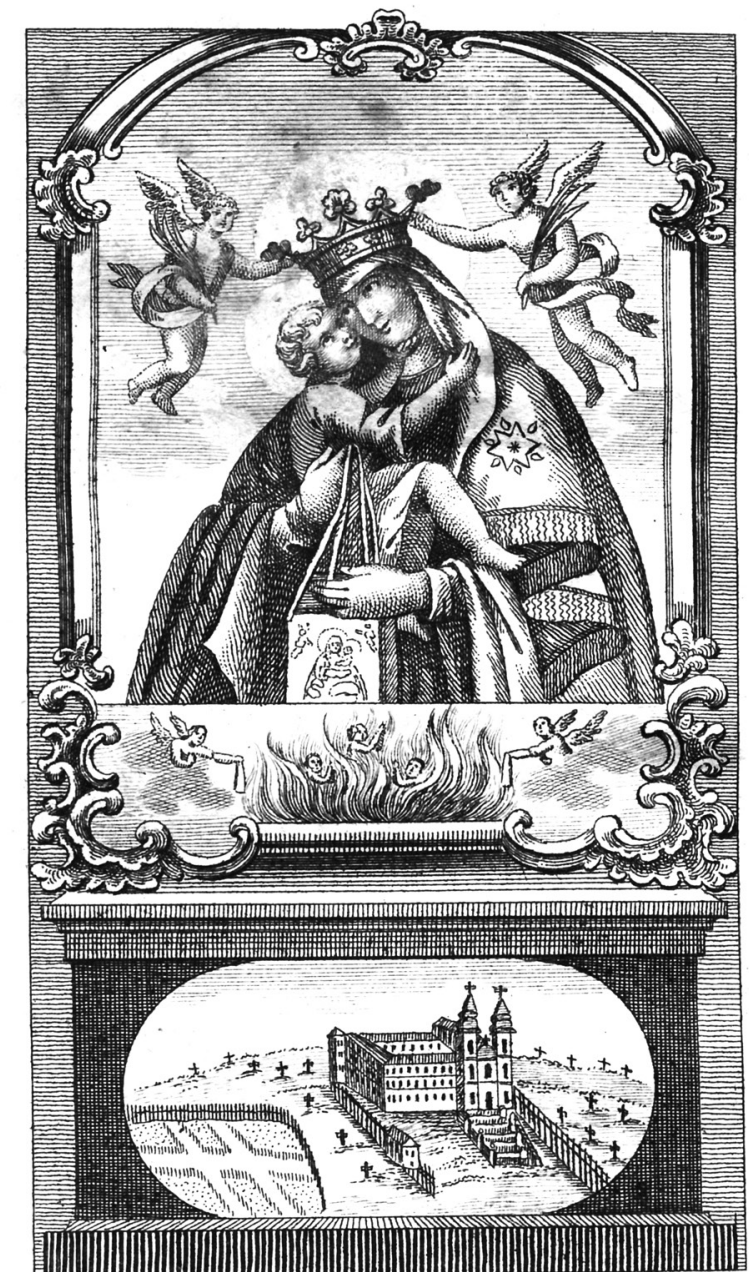

12. A máriaradnai kegyképet a templommal ábrázoló 1771/1773-ból ismeretes címlapelózék újra metszett (4.) változata (1824)

telenül, a Világos Berkes-hegy elbúvölően együgyű fametszeteivel megszerezve jelenik meg." ${ }^{\prime 2}$ Ugyanakkor azt is meg kell említenünk, hogy az 1810. évi korábbi szegedi kiadásban nem szerepelt a fametszetsorozat. A feltételezhetően még a 19. század közepén mindig használható állapotú képsorozat további sorsáról jelenleg nincs információnk. A század második felében kiadott nyomtatványban már új metszésű fametszetsorozatot alkalmaztak. A budai Landerer-nyomdát megvásároló Bagó Márton 1856-ban szintén horvát nyelven adta ki a máriaradnai Skapulárés Szúzanya csodatételét elmesélő kötetet. ${ }^{43} \mathrm{Az}$ ebben szerepeltetett hat tagból álló fametszetsorozat képi ábrázolása bár esetenként ugyan tartalmában követi, de megjelenítésében jelentősen eltér a 18. századi budai Landererféle nyomtatványokban előforduló Binderhez, illetve múhelyéhez kötődő illusztrációktól, azzal nem azonos. 


\section{FÜGGELÉK}

Binder János Fülöpnek a budai Landerer-tipográfia kiadványaiban megjelent, a máriaradnai kegyképet ábrázoló metszetei (1762-1771)

\section{Címlapelőzék}

1. A máriaradnai kegykép, alatta a templom és a kolostor látképével. 1. változat, jelölve: "I. Philipp Binder. Sc. Budae." Felirata: Monstra te esse matrem. Duc eum ad Mariam. Egeni aspicite matrem. Ecce matrem vestram. $(119 \times 69 \mathrm{~mm})-$ Petrik I. 249, címlapelőzék, Petrik V. 302, címlapelőzék

Megjelent: Világos berkes hegy,... Budán, Landerer Ferencz Leopold Betüivel, 1762-dik Esztendőben (Petrik I. 249).

Megjegyzés: az 1763. és az 1767. évi kiadásokból kitépték a címlapelőzéket, de minden bizonnyal e két kiadás esetében is az ismert Binder-féle metszet szerepelt a címlap előtt.

Nem tévesztendő össze a 2. számú, azonos utánmetszett változattal:

Megjelent: Stanislaus Losgott: Varta pietatis exercitia,.... Budae typis Leopoldi Francisci Landerir, 1769. (Petrik V. 302).

Használata: Buda, 1762, [1763, 1767], 1769.

2. A máriaradnai kegykép, alatta a templom és a kolostor látképével. Rézmetszet, felirata: Monstra te esse matrem. Duc eum ad Mariam. Egeni aspicite matrem. Ecce matrem vestram. Binder képének (1. számú címlapelőzék utánmetszett) 2. változata, jelölve: „I Philipp Binder. sc. Budae [?]” olvashatatlan, nem eldönthető, hogy Binder, vagy ismeretlen, a Binder-féle műhelyben dolgozó metsző munkája! (115×70 mm) - Petrik V. 554 (1771, rézmetszetsorozat), címlapelőzék

Megjelent: Wunderscheinender Wald-Schatten... Ofen, gedruckt mit Landerischen Schriften. 1771. (Petrik V. 554, (1771, rézmetszetsorozat).

Irodalom: Szilárdfy-Tüskés-Knapp (3. jegyzetben) i. m. 190. tétel; Rózsa (2. jegyzetben) i. m. 1998, 163. tétel.

Használata: Buda, 1771.

3. A máriaradnai kegykép, alatta négykaréjú kartusban a templom és a kolostor látképével. Rézmetszet. Újrametszett változat, jelölve: „Binder sc. Budae" $(118 \times 68,5 \mathrm{~mm})$ - (Petrik V. 554) (1771, fametszetsorozat)

Megjelent: Wunderscheinender Wald-Schatten... Ofen, gedruckt mit Landerischen Schriften. 1771. (Petrik V. 554) (1771, fametszetsorozat)
Megjegyzés: a kitépett címlapelőzék rézmetszete azonos az 1773. évi temesvári magyar nyelvü kiadásban található címlapelőzék-metszettel. Irodalom: Szilárdfy-Tüskés-Knapp (3. jegyzetben) i. m. 191. tétel; Rózsa (2. jegyzetben) i. m. 169.

Használata: [Buda, 1771].

18. századi utóélete: Temesvár, 1773.

4. A máriaradnai kegykép, alatta nyújtott ovális emblémában a templom és a kolostor látképével. Rézmetszet. A 3. számú címlapelőzék-metszet utánmetszett változata, jelöletlen, $(112 \times 63 \mathrm{~mm})$ Megjelent: Világos Berkes-hegy... Pest, Trattner János Tamás betưivel 1824 .

Használata: Pest, 1824.

\section{Rézmetszetsorozat (13. kép)}

A máriaradnai kegyhelyhez kötődő magyar és német nyelvü mirákulumos könyv rézmetszetsorozata (11 darab, mert a 6. sz. metszet kétszer szerepel). A sorozatnak csak az első tagja jelölve: „J. P. Binder sc. Budae." a többi jelöletlen.

Megjegyzés: a 11. kép esetében a sorozat eredeti tagja [11a] csak 1762-1767 között volt használatban, 1771-ben az újra metszett változat [11b] szerepelt.

Megjelent: Világos berkes hegy,... Budán, Landerer Ferencz Leopold Betüivel, 1762-dik Esztendőben (Petrik I. 249).

Wunder-scheinender Wald-Schatten Oder Ausfuhrlicher Bericht des wunderthätigen GnadenBildes der aller seeligsten Jungfrauen Mariae.... Ofen, gedruckt bey Leopold Franz Landerer, 1763. (Petrik III. 822).

Wunder-scheinender Wald-Schatten oder ausfuhrlicher Bericht des wunderthätigen Gnaden, Bildes der allerseligsten Jungfrauen Mariae.... Ofen, gedruckt bey Leopold Franz Landerer, 1767. (Petrik V. 554)

Wunderscheinender Wald-Schatten... Ofen, gedruckt mit Landerischen Schriften. 1771. (Petrik V. 554) (1771, rézmetszetsorozat).

Irodalom: Knapp-Tüskés (12. jegyzetben) 1996 i. m. 30.; Knapp-Tüskés (12. jegyzetben) i. m. 136-139.; Rózsa (2. jegyzetben) i. m. 117-128. tétel Használata: Buda, 1762-1771.

1. kép: Vrichnossa György egy olasz képkereskedőtől megvásárolja a későbbi Skapulárés Szűzanya kegyképét. Szign. J. P. Binder sc. Budae $(50,5 \times 61)-$ Petrik I. 249, 2., Petrik III. 822, 2., Petrik V. 554 (1767), 2., Petrik V. 554 (1771), 2. 1. 

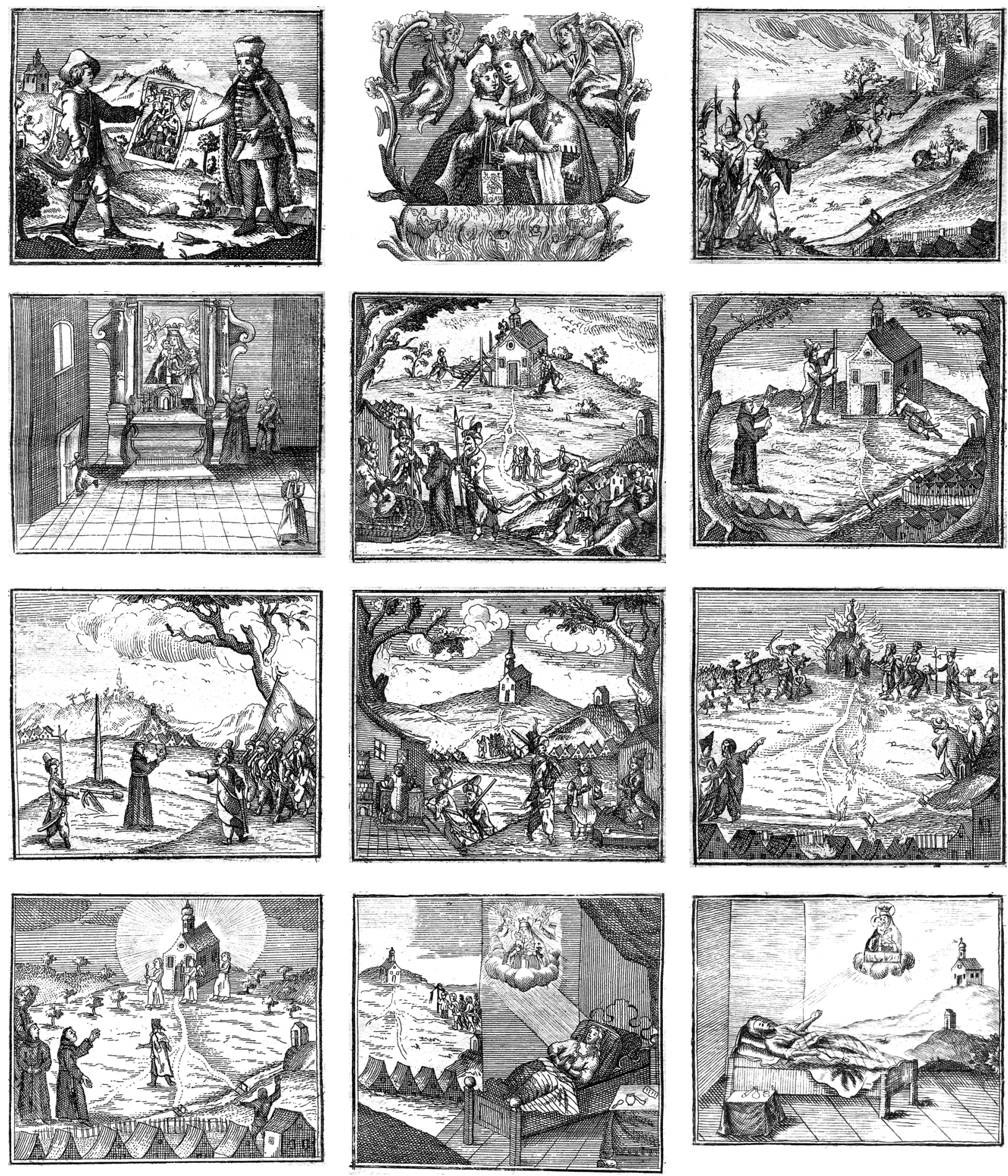

13. A máriaradnai kegyhelyhez kötődő magyar és német nyelvú mirákulumos könyv rézmetszetsorozata

2. kép: a máriaradnai kegykép - Mária (Skapulárés Szúzanya) mint a Menny és a Föld királynéja, alatta a tisztítótűzben szenvedő, Mária segítségét kérő lelkek. $(51 \times 59)$ - Petrik I. 249, 4., Petrik III. 822, 4., Petrik V. 554 (1767), 4., Petrik V. 554 (1771, rézmetszetsorozat), 4.1 .
3. kép: a török felgyúitja a radnai templomot, de a máriaradnai kegykép sértetlen marad $(52 \times 63)-$ Petrik I. 249, 7., Petrik III. 822, 6, Petrik V. 554 (1767), 6., Petrik V. 554 (1771, rézmetszetsorozat), 6. 1.

4. kép: a máriaradnai kegykép nyakékét ellopni készüló leány hozzáragad a kegyképhez $(54 \times 62,5)$ - 
Petrik I. 249, 10., Petrik III. 822, 8., Petrik V. 554 (1767), 8., Petrik V. 554 (1771, rézmetszetsorozat), 8. 1.

5. kép: a máriaradnai templom felújítása miatt a törökök elfogják Jánich András atyát, akit a lippai bég megverettet $(52 \times 60,5)$ - Petrik I. 249, 15., Petrik III. 822, Petrik V. 554 (1767), 14., Petrik V. 554 (1771, rézmetszetsorozat), 14.1 .

6. kép: A török szultán írásos engedélyével felújítják a radnai templomot $(52 \times 64)$ - Petrik I. 249, 17., 32., Petrik III. 822, 16., 26., Petrik V. 554 (1767), 16., 26., Petrik V. 554 (1771, rézmetszetsorozat), 16., 26. 1.

7. kép: a halálra ítélt Jánich András atya a török szultán írásos engedélyét felmutatva megmenekül. (52×60) - Petrik I. 249, 22., Petrik III. 822, 19., Petrik V. 554 (1767), 19., Petrik V. 554 (1771, rézmetszetsorozat), 19. 1. Buda, 1762-1771.

8. kép: a templomon kívüli istentisztelet miatt megvádolt Plumboi János atyát a hívek megvédelmezik a törökök vádjaitól. $(53 \times 60,5)$ - Petrik I. 249, 27 ., Petrik III. 822, 24., Petrik V. 554 (1767), 24., Petrik V. 554 (1771, rézmetszetsorozat), 24.1.

9. kép: a máriaradnai templomot felgyújtó törököket isten megbünteti. $(53 \times 60)$ - Petrik I. 249, 36., Petrik III. 822, 30., Petrik V. 554 (1767), 30., Petrik V. 554 (1771, rézmetszetsorozat), 30.1.

10. kép: Mária-ünnepeken a máriaradnai templom fényességben tündököl. $(52,5 \times 60,5)$ - Petrik I. 249, 43., Petrik III. 822, 35., Petrik V. 554 (1767), 35., Petrik V. 554 (1771, rézmetszetsorozat), 35. 1.

11a. kép: Brumer Anna Mária látomása, a radnai zarándoklat kezdete: a kép bal oldalán a máriaradnai templomhoz zarándokolók, jobb oldalán a beteget gyógyító máriaradnai kegykép, alatta Brumer Anna Mária. $(53 \times 59)$ - Petrik I. 249, 55., Petrik III. 822, 43., Petrik V. 554 (1767), 43.1.

11b. kép: tükörfordított, de nem pontos újrametszett változata a 11a sz. képnek. $(51,5 \times 64)$ - Petrik V. 554 (1771, rézmetszetsorozat), 43. 1.

\section{Fametszetsorozat (14. kép)}

A máriaradnai kegyhelyhez kötődő német nyelvü mirákulumos könyvben elöforduló duplán keretezett fametszetsorozat (11 darab, mert a 6. sz. metszet kétszer szerepel)

Megjegyzés: a fametszetsorozat az eredeti rézmetszetsorozat alapján készült.

Megjelent: Wunderscheinender Wald-Schatten ... Ofen, gedruckt mit Landerischen Schriften. 1771. (Petrik V. 554 1771, fametszetsorozat)

Világos Berkes-hegy ... Budán, a Királyi Universitásnak betüivel 1805.

Istinito izpisanje csuddotvorne prilike B. D. Marie koja u Radnoj, sverhu 150. godinah veche, od bogoljubnih kerstjanah poboxno se shtuje ... / za vishu slavu Boxju i B. D. Marie ... iz latinskoga u slavonski jezik, po Marianu Jaichu ... prinesheno.

[Radnai történetek. Szeged, 1843 Grün ny. ?]

Irodalom: Bálint Sándor (37. jegyzetben) i. m. 815; Knapp - Tüskés (12. jegyzetben) 1996, i. m. 30.; Knapp - Tüskés (12. jegyzetben) 2004, i. m. 136-139.

Használata: Buda, 1771.

18. századi utóélete: 1773. Temesvár, 1796 Vác.

19. századi utóélete: Buda, 1805, Arad 1824. Szeged 1843 ?

1. kép: Virchnossa György megvásárolja a Skapulárés Szüzanya képét. $(50 \times 62)$ - Petrik V. 554 (1771, fametszetsorozat), 2.1.

2. kép: A máriaradnai kegykép - Mária (Skapulárés Szüzanya) mint a Menny és a Föld királynéja, alatta a tisztítótüzben szenvedő, Mária segítségét kérő lelkek. $(53 \times 62)$ - Petrik V. 554 (1771, fametszetsorozat), 4.1 .

3. kép: a török felgyújtja a radnai templomot, de a máriaradnai kegykép sértetlen marad. $(52 \times 62)-$ Petrik V. 554 (1771, fametszetsorozat), 6. 1.

4. kép: a máriaradnai kegykép nyakékét ellopni készülő leány hozzáragad a kegyképhez. $(54 \times 62)$ Petrik V. 554 (1771, fametszetsorozat), 8. 1.

5. kép: a máriaradnai templom felújítása miatt a törökök elfogják Jánich András atyát, akit a lippai bég megverettet. $(54 \times 62)$ - Petrik V. 554 (1771, fametszetsorozat), 14.1 .

6. kép: a török szultán írásos engedélyével felújítják a radnai templomot. $(53 \times 62)$ - Petrik V. 554 (1771, fametszetsorozat), 16, 25. 1.

7. kép: a halálra ítélt Jánich András atya a török szultán írásos engedélyét felmutatva megmenekül. $(52 \times 62,5)$ - Petrik V. 554 (1771, fametszetsorozat), 18. 1 .

8. kép: a templomon kívüli istentisztelet miatt megvádolt Plumboi János atyát a hívek megvédelmezik a törökök vádjaitól. $(53 \times 62)$ - Petrik V. 554 (1771, fametszetsorozat), 23. 1.

9. kép: a máriaradnai templomot felgyújtó törököket Isten megbünteti. $(54,5 \times 62)$ - Petrik V. 554 (1771, fametszetsorozat), 29. 1.

10. kép: Mária-ünnepeken a máriaradnai templom fényességben tündököl. $(53 \times 62)$ - Petrik V. 554 (1771, fametszetsorozat), 34. 1.

11. kép: Brumer Anna Mária látomása, a radnai zarándoklat kezdete: a kép jobb oldalán a máriaradnai templomhoz zarándokolók, bal oldalán a beteget gyógyító máriaradnai kegykép, alatta Brumer Anna Mária. $(55 \times 62)$ - Petrik V. 554 (1771, fametszetsorozat), 41. 1. 

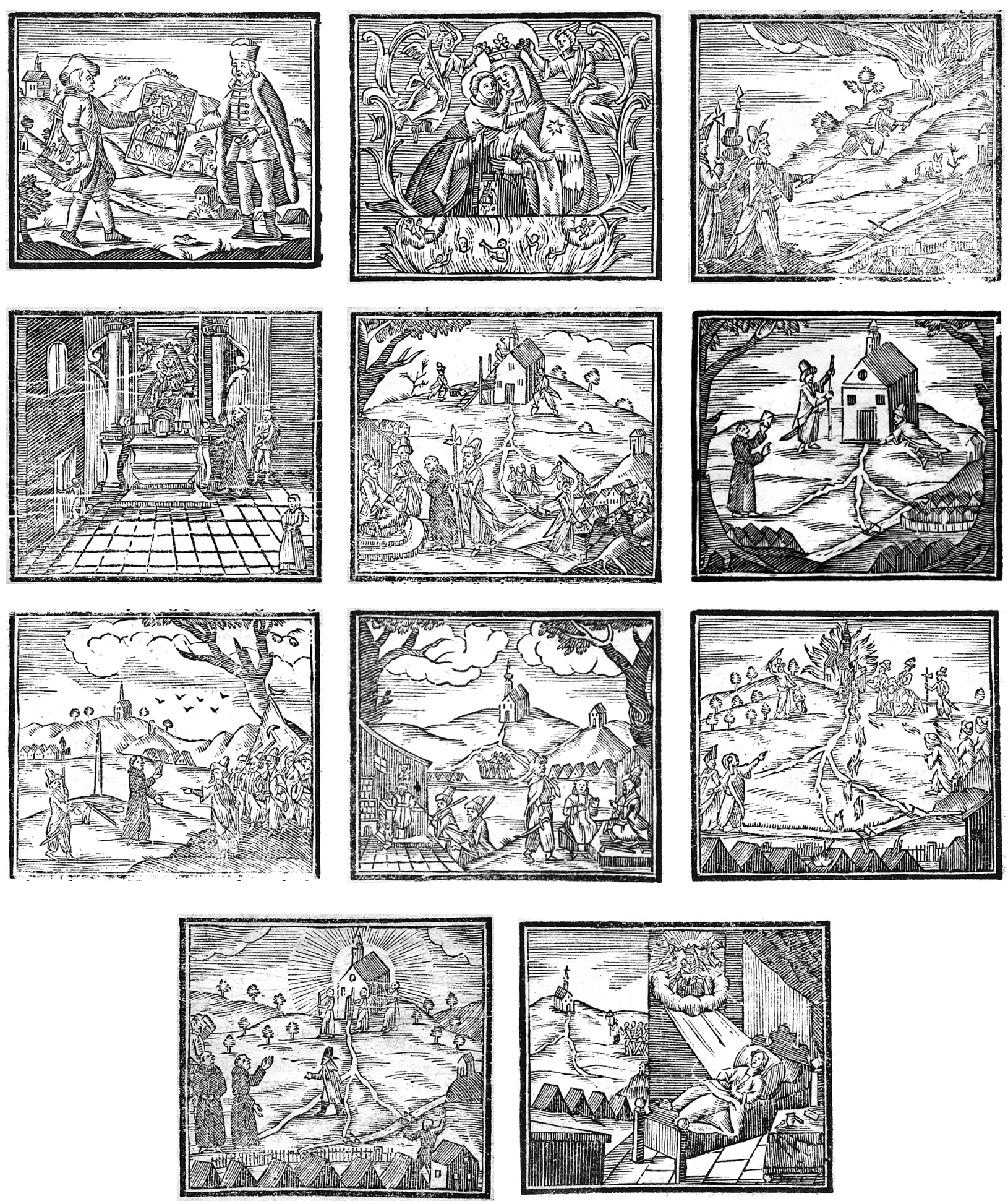

14. A máriaradnai kegyhelyhez kötődő német nyelvú mirákulumos könyv duplán keretezett fametszetsorozata 


\section{JEGYZETEK}

1 A tanulmány az OTKA 104231 számú kutatási programja keretében készült. Mindvégig - a bevett Petrik rövidítéssel - hivatkozunk Petrik Géza sokkötetes, öszszegző bibliográfiájára: Magyarország bibliographiája, 1712-1860 / Bibliographia Hungariae 1712-1860. Összeáll. Petrik Géza. Budapest, Országos Széchényi Könyvtár, 1968-1991.

2 Rózsa György: Grafikatörténeti tanulmányok. (Müvészettörténeti füzetek, 25.) Budapest 1998, 61.

3 Uo. - Ennél korábban, az 1750-es évek elején a budai Landerer-mühelyben nyomtatott imalapokról tesz említést: Szilárdfy Zoltán - Tüskés Gábor - Knapp Éva: Barokk kori kisgrafikai ábrázolások magyarországi búcsújáróhelyekről. Budapest 1987, 51. és 59. tétele.

4 Paulus Lucas Perghold: De rege et cive... Budae Typis Leopoldi Francisci Landerer Typographi. (Petrik III. 70, 15).

$5 \mathrm{Az}$ uralkodó iránti hűséget szimbolizáló allegorikus kép $(195 \times 144 \mathrm{~mm})$ alatt hatsoros latin nyelvű emblémavers olvasható. A kép alatt jobbra lent látható a szignatúra: I. Phil. Binder sc. Budae. A Binder-féle metszetet Landerer az 1766. évi kiadásban is felhasználta (Petrik III. 70).

6 Joann Elem os. Ferdinand Miller: Epitome vicissitudinum ez rerum... urbe Budensi,... Budae, Typis Leopoldi Francisci Landerer Typog. Ad Auream Navem. 1760. [1761.] (Petrik II. 742, 82-83 sz. oldalak közé beillesztve). - Buda $287 \times 453$ milliméteres látképe 1 . Rózsa (2. jegyzetben) i. m. 107. sz. tétel.

7 Barna Gábor megállapítása szerint a Kármelhegyi Boldogasszonyt ábrázoló máriaradnai kegykép „nem a bécsi karmeliták képével áll kapcsolatban, hanem attól különálló és önálló leszármazási utat mutat". Barna Gábor: Évszázados tudásrétegek máriaradnai képeken. A tisztítótüz Máriaradna 17. századi kegyképén, valamint a mennyország, a purgatórium és a pokol egy 20. századi (naiv) képen. In: Menny és pokol a barokk kori ember életében. Szerk. Báthory Orsolya. Budapest 2014, 28.

8 A máriaradnai kegyképet az észak-itáliai Bassanóban, az 1660-as években a Remondini-tipográfiában nyomtatták ki. Nemorosa opacitas relucens,... Budae, Typis Leopoldi Francisei Landerer, 1756. (Petrik II. 928), 10. Itt Georgius Vrichonossa névforma olvasható. Barna (7. jegyzetben) i. m. 27.

9 A máriaradnai búcsújárással foglalkozó legfontosabb szakirodalom Bálint Sándor: Boldogasszony vendégségben. Budapest 1944; Bálint Sándor - Barna Gábor: Búcsújáró magyarok. Budapest 1994. 249).

10 Világos Berkes-hegy... Temesvár 1773. (Petrik I

11 Világos Berkes-hegy... Vác 1796. (Petrik V. 542).

12 Knapp Éva - Tüskés Gábor: Barokk kori mirákulumos könyvek illusztrációsorozatai. Magyar Könyvszemle CXII. 1996, 30-32; Knapp Éva - Tüskés Gábor: Populáris grafika a 17-18. században. Budapest 2004, 138-139.

13 Nemorosa opacitas relucens seu genuina historia sacratissimae imaginis Beatissimae Virginis Matris Gratiarum,... Budae, Typis Leopoldi Francisei Landerer, Typog. 1756. (Petrik II. 928).

14 Világos berkes hegy,... Budán, Landerer Ferencz Leopold Betüivel, 1762-dik esztendőben (Petrik I. 249).
15 Ez a $119 \times 69$ milliméteres címlapelőzék-metszet nem szerepel sem a Szilárdfy Zoltán - Tüskés Gábor Knapp Éva, sem a Rózsa György által készített összeállításban. Mindannyian az 1771. évi kiadásban szereplő címlapelőzéket említik (3. kép), egyúttal azt is megjegyezve, hogy az Országos Széchényi Könyvtárban őrzött „példány időközben eltünt”. Vö. Szilárdfy-Tüskés-Knapp (3. jegyzetben) i. m. 190. tétel; Rózsa (2. jegyzetben) i. m. 163. tétel. Az általuk hivatkozott címlapelőzék-metszet napjainkban megtalálható a magyar nemzeti könyvtár gyưjteményében (jelzete: 319.358). Ez a metszet azonban nem azonos az 1762. évi eredeti Binder által jelölttel, hanem annak utánmetszett későbbi változata (1. a 2-3. kép).

16 Stanislaus Losgott: Varia pietatis exercitia,... Budae typis Leopoldi Francisci Landerer, 1769. (Petrik V. 302).

17 Wunder-scheinender Wald-Schatten. ... Ofen, gedruckt bey Leopold Franz Landerer, 1763. (Petrik III. 822). $\mathrm{Az}$ 1763. évi kiadásból két példányt ismerünk, amelyek az Országos Széchényi Könyvtár (jelzete: Mor 5842) és a kalocsai Főszékesegyházi Könyvtár (jelzete: C 1764) gyűjteményében találhatók.

18 Wunder-scheinender Wald-Schatten oder ausfuhrlicher Bericht des wunderthätigen Gnaden, Bildes der allerseligsten Jungfrauen Mariae. ... Ofen, gedruckt bey Leopold Franz Landerer, 1767. (Petrik V. 554). Egyetlen példányát a Fővárosi Szabó Ervin Könyvtár Központi gyüjteménye őrzi (jelzete: B 231/1).

19 Wunderscheinender Wald-Schatten,... Ofen, gedruckt mit Landerischen Schriften. 1771. (Petrik V. 554 (rézmetszetsorozattal) és Wunderscheinender WaldSchatten,... Ofen, gedruckt mit Landerischen Schriften. 1771. (Petrik V. 554, fametszetes sorozat).

20 Knapp-Tüskés (12. jegyzetben) 1996 i. m. 30; KnappTüskés (12. jegyzetben) i. m. 138.

21 A $115 \times 70$ milliméteres utánmetszett változatot (3. kép) említi Rózsa (2. jegyzetben) i. m. 163. tétel; SzilárdfyTüskés-Knapp (3. jegyzetben) i. m. 190. tétel.

22 Tüskés Anna: Pilgrimage Art in Eighteenth Century Transylvania. Icons, Woodcuts and Engravings. In: Economy and Society in Central and Eastern Europe. Territory, Population, Consumption. Ed. Daniel Dumitran - Valer Moga. Wien-Zürich 2013, 208.

23 Saját kezű alkotásai esetében Binder többnyire a teljes nevét jelölte, de a csak a vezetéknevével szignált metszetek inkább budai műhelye közreműködésére utalnak, és ezek általában mind gyengébb minőségűek is voltak. Rózsa (2. jegyzetben) i. m. 61.

24 Világos berkes hegy... Temesvár, 1773. (Petrik I. 249). 25 Szilárdfy-Tüskés-Knapp (3. jegyzetben) i. m. 191. tétel. 26 L. 16. számú jegyzet.

27 Knapp-Tüskés (12. jegyzetben) 1996 i. m. 30; KnappTüskés (12. jegyzetben) i. m. 136-139; Rózsa (2. jegyzetben) i. m. 117. tétel, a szignó. J. P. Binder sc. Budae. Ennek alapján Rózsa György a sorozat többi tagját is Binder művének tekintette: 1. a 118-128. tételeket.

28 Wunderscheinender Wald-Schatten,... Ofen, gedruckt mit Landerischen Schriften. 1767. (Petrik V. 554).

29 Wunderscheinender Wald-Schatten,... Ofen, gedruckt mit Landerischen Schriften. 1771. (Petrik V. 554, (rézmetszetsorozattal), A3-4. 
30 Világos berkes hegy... Temesvár 1773. (Petrik I. 249). 31 Világos berkes hegy... Vác 1796. (Petrik V. 542).

32 Vizkelety-Ecsedy Judit: Vermutliche und tatsächliche Druckorte im Banat. pp. In: Deutsche Sprache und Kultur im Banat. Hrsg. Wynfrid Kriegleder - Andrea Seidler - Jozef Tancer. (Presse und Geschichte, Neue Beiträge, Bd. 87.) Bremen 2015, 39-50.

$33 \mathrm{Az}$ Országos Széchényi Könyvtár gyűjteményében fellelhető egyetlen példányból (jelzete: 131.535) hiányzik a címlapelőzék. Vannak azonban arra utaló jelek, hogy egykoron a címlap előtt beragasztott címlapelőzék lehetett.

34 Világos Berkes-hegy... Budán, a Királyi Universitásnak betüivel 1805.

35 Világos Berkes-hegy... Pesten, Petrózai Trattner János Tamás betüivel 1824 .
36 Beschreibung der Gnadenbilder der seligsten Jungfrau Mutter Gottes Maria, welche im Königreich Hungarn... verehrt werden: nach dem Vortritte der zwei, von Paul Eszterás... herausgegebenen Bücher ... / [zgest. und] hrsg. Jordánszky Elek. 1836, 101.

37 Istinito izpisanje csuddotvorne prilike B. D. Marie koja u Radnoj, sverhu 150. godinah veche, od bogoljubnih kerstjanah poboxno se shtuje... U Aradu: pritiskano slovima Antuna Michecka..., 1824.

38 Izvorna poviestnica milostivo-čudotvorne prilike Gospe Radnanske... U Budimu: šlovima M. Bagó, 1856. 39 Dugonics András: Radnai történetek. Szeged 1810. 40 Radnai Történetek. Szeged 1843.

41 Bálint Sándor: Az Etelka és Máriaradna. (Dugonics András írói mühelyéből). Vigilia XXXIII. 1968, 812-815. 42 Uo. 815.

43 L. 37. jegyzet.

\section{ILLUSTRATIONS BY JÁNOS FÜLÖP BINDER CONNECTED TO MÁRIARADNA IN THE MIRACLE-BOOKS ISSUED BY THE LANDERER-PRESS IN BUDA}

The miraculous escape of the icon of Máriaradna representing Our Lady of the Carmel Mountain (originally a coloured woodcut sheet of Italian origin) had a longlasting effect on 18th century Hungarian popular religious literature. To our present knowledge the Landerer printing workshop issued it between 1756-1771/1773? in Latin, Hungarian and German languages, in altogether seven editions. The unknown author tells how the icon escaped and also the miraculous events effected by the icon. From 1762 on these editions were decorated with illustrations: an engraved frontispiece and a series of engraved images telling the history of the icon. Later beside the engraved series of images woodcut technique was also employed.

As a result of the systematic reconstruction of the typographical and decorative elements employed in the Landerer-press carried on by the author several new facts can be stated. First of all, the Landerer office employed three variants of the engraved frontispiece, of which the first was the one signed by Johann Philipp Binder in the 1762 Hungarian edition. The next was a variant, an after-cut of Binder's, while the third is an image of quite different concept as compared to the previous two ones, although all the three represent Our Lady of Radna, with the child Jesus, and the church of Máriaradna, the place of worship. The two later ones were used from 1771 and were the products of the copper-plate engraving workshop in Buda founded by Binder. The practice of the workshop was to sign their works only shortly as "Bind$\mathrm{er}^{\prime \prime}$. The series of engraved illustrations telling the history of the shrine was also used from 1762 on, but some time between 1771 and 1773 the pictures were copied to woodcuts, probably also in the Binder workshop. Although the paper highlights on the 18th century Buda editions of the miracle book and its illustration, mention is also made on the survival and after-life of illustrations related to the Máriaradna icon.

Kulcsszavak: Johann Philipp Binder, Landerer-nyomda, Máriaradna, ikonográfia, fametszet, rézmetszet, kegykép, Kármelhegyi Boldogasszony, 18. század, Buda, Temesvár, Vác / Keywords: Johann Philipp Binder, Landerer press, Máriaradna (Radna, today Romania), iconography, woodcut, copper-plate engraving, icon, Our Lady of Carmel Mountain, 18th century, Buda, Temesvár (Timişoara, today Romania), Vác

Bánfi Szilvia, Budapest, Országos Széchényi Könyvtár / National Széchényi Library, banfi@oszk.hu 